\title{
New evidence for possible generation of oil off south-western Greenland
}

\author{
Troels Laier and Hans Peter Nytoft
}

In 2011, traces of bitumen in the 1160 Ma old Ilímaussaq intrusion in South Greenland have been examined in order to determine their origin. The investigation was prompted by the recent interest in hydrocarbon exploration off western Greenland, an interest expressed in the form of four new licences in the region (Christiansen 2011). The hydrocarbon potential in the region was realised after reinterpretation of seismic profiles across the Labrador Sea, and this indicates the presence of a sedimentary basin off south-western Greenland (Fig. 1; Chalmers \& Pulvertaft 2001). However, the main problem in petroleum exploration off south-western Greenland is that no prolific marine source rocks have been demonstrated (Christiansen 2011). Therefore, any trace of hydrocarbons, however small that may help demonstrate the occurrence of source rocks in the region, deserves careful examination.

Recently, bitumen biomarkers have been used to question the presumed abiogenic origin of hydrocarbons in crystalline rocks of the Ilímaussaq intrusion (Laier \& Nytoft 2012). In this paper, we focus on the origin of the bitumen and compare it with previous finds in central West Greenland. The presence of hydrocarbons in the Ilímaussaq intrusion has been known since 1970 (Petersilie \& Sørensen 1970) but unlike the discovery of oil seeps in the Nuussuaq region in central West Greenland twenty years later, which had a positive impact on petroleum exploration (Christiansen 2011), the hydrocarbons in the Ilímaussaq intrusion were largely ignored in the context of offshore exploration. The reason for this is twofold: (1) hydrocarbons in the Ilímaussaq intrusion are much more difficult to recognise than on Nuussuaq, and (2) analytical results are confusing with respect to the origin of the hydrocarbons. Discrete millimetre-size hydrocarbon accumulations have only been observed twice, and samples of this material were unfortunately not available for analysis in the present investigation. The material, which is a waxy paraffinic hydrocarbon of $\mathrm{C}_{28} \mathrm{H}_{56}$, was located in vugs of pegmatite veins and labelled as an evenkitelike mineral by Konnerup-Madsen et al. (1979). Otherwise hydrocarbons in the Ilímaussaq intrusion only exist in fluid inclusions, mainly as $\mathrm{C}_{1}-\mathrm{C}_{5}$, and as dispersed bitumen invisible to the naked eye. The stable carbon isotopic ratio of me- thane $\left(\delta^{13} \mathrm{C}=-7 \%\right.$ o) released from the inclusions by crushing (Petersilie \& Sørensen 1970) differed from that of associated methane in most oil and gas reservoirs, which has $\delta^{13} \mathrm{C}$ values of -30 to $-50 \%$. The ratio was closer to the isotopic ratio of primodial carbon of the Earth's mantle, which has $\delta^{13} \mathrm{C}$ values around $-5 \%$. The paraffinic hydrocarbons of 'evenkite' on the other hand had a $\delta^{13} \mathrm{C}$ value of $-29 \%$, which is within the expected range for hydrocarbons generated by thermal maturation of organic matter (Konnerup-Madsen et al. 1988).

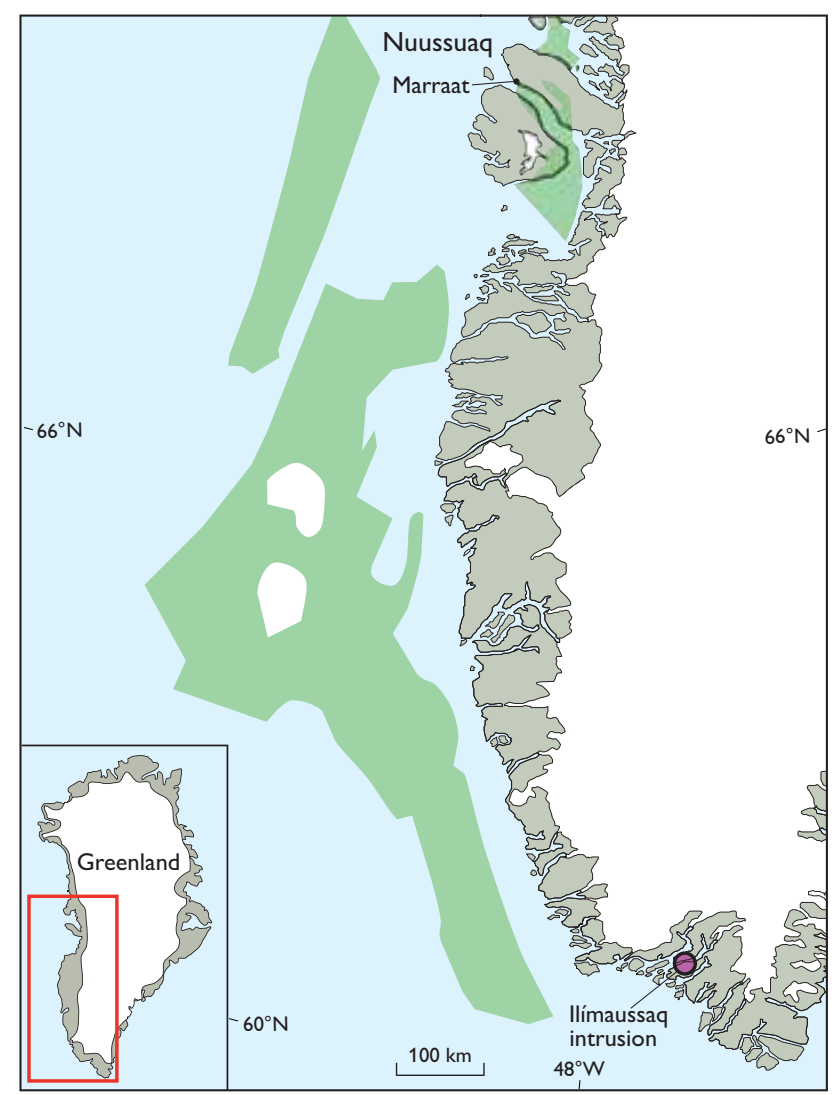

Fig. 1. Map of south-western Greenland showing the distribution of Mesozoic/Cenozoic rift basins offshore (green). Modified from Chalmers \& Pulvertaft (2001). Oil seeps occur on Nuussuaq. 

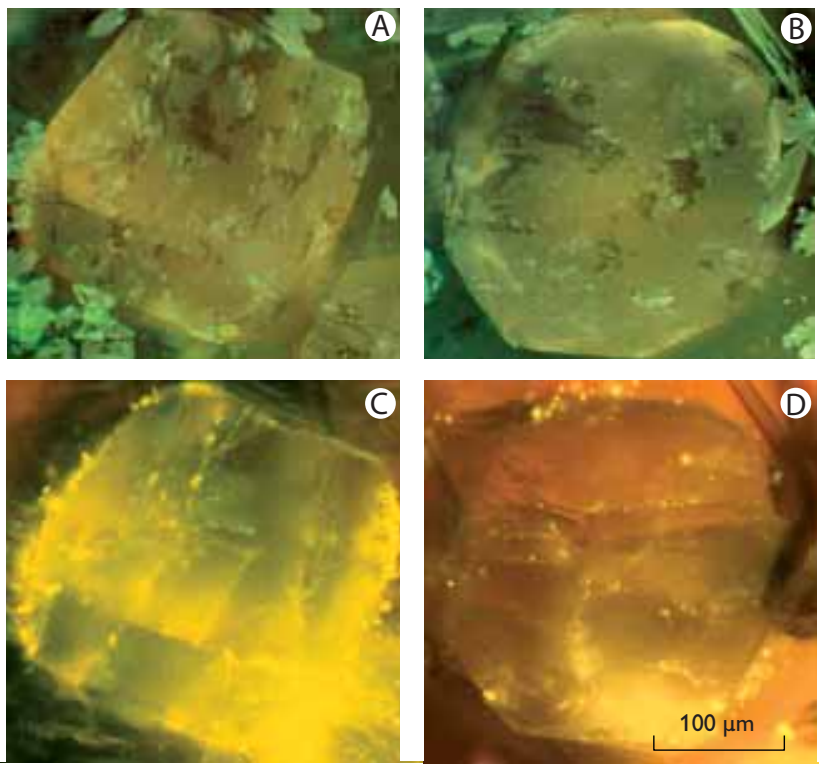

Fig. 2. Photomicrographs of lujavrite (GGU 57033) viewed under visible light $(\mathbf{A}, \mathbf{B})$ and in ultraviolet light $(\mathbf{C}, \mathbf{D})$ showing hydrocarbons along the edges of eudialyte crystals and as traces of tiny inclusions within the crystals.

\section{Dispersed bitumen in crystalline rocks}

The distribution of bitumen was examined by microscopy using ultraviolet light, which causes the aromatic constituents of bitumen to fluoresce. Unfortunately, a number of the rather common minerals, e.g. sodalite, in different rock types of the Ilímaussaq intrusion also fluoresce strongly making it almost impossible to indentify traces of bitumen with certainty in some samples. Lujavrite contains only little sodalite and offers the best possibility to study the distribution of bitumen (Fig. 2). The bitumen occurs along crystal edges and as trails of tiny inclusions within single crystals of, for example, eudialyte. Trails of tiny inclusions are usually taken as evidence of a secondary origin formed in healed fractures. Thus hydrocarbons probably migrated through the rock and were trapped in certain minerals.

\section{Bitumen content and composition}

It was possible to extract bitumen from naujaite, kakortokite and lujavrite, which are the three major rock types in the Ilímaussaq intrusion, by using a 7:1 mixture of dichloromethane and methanol. The bitumen content varied from 110 to $300 \mathrm{mg}$ per $\mathrm{kg}$ rock and consisted of paraffins (20\%), aromates (20\%), NSO compounds (compounds with nitrogen, sulphur and oxygen; 50\%) and asphaltenes (10\%). The nonpolar fraction from the different rock extracts was analysed by gas chromatography with a flame-ionisation detector for total composition and mass spectrometry for biomarker
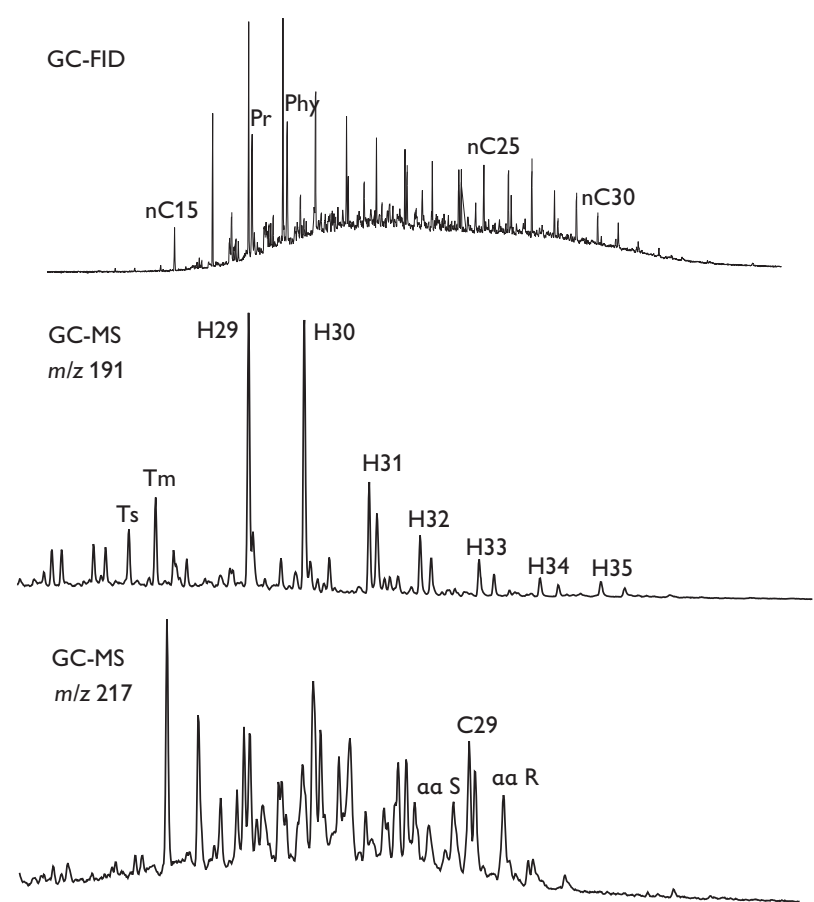

Fig. 3. Chromatograms of the aliphatic fraction of extract from Ilímaussaq kakortokite $m / z 191$ (hopanes+tricyclic) and $m / z 217$ (steranes). FID: flame ionisation detector, GC-MS: gas chromatography - mass spectrometry.

characterisation (Fig. 3). All samples gave very similar $\mathrm{m} / \mathrm{z}$ 217 chromatograms showing a typical marine sterane distribution, although the presence of oleananes in the $\mathrm{m} / \mathrm{z} 191$ chromatogram suggests some input from land plants. Oleananes are derived from angiosperms, which appeared in the Late Cretaceous, and hence the presence of oleananes provides a maximum age for the source of the bitumen. Since other triterpanes are known to co-elute with oleananes, gas chromatograph mass spectrometry (GC-MS-MS) was also conducted to confirm their presence (Fig. 4). The GC-MSMS analysis not only confirmed the presence of oleananes but also showed the existence of bicadinanes, which is a less common group of biomarkers from land plants from Late Cretaceous or Tertiary. Oleananes and bicadinanes were also observed in oil seeps from the Nuussuaq region (Fig. 4; Bojesen-Koefoed et al. 1999; Nytoft et al. 2002).

\section{Migration and entrapment of hydrocarbons}

Not only is bitumen much more difficult to recognise in rocks from the Ilímaussaq intrusion than in basalts from Nuussuaq, but the migration route of hydrocarbons to the Ilímaussaq intrusion is also less evident. In Nuussuaq the oil seeps are found in Tertiary plateau basalts overlying Cretaceous and Tertiary sediments, some of which are potential 
source rocks. In the Ilímaussaq intrusion, the bitumen is found in Proterozoic crystalline rocks which are much older than the source rock, which is not older than Late Cretaceous as shown by the presence of oleanes and bicadinanes. In contrast to the Nuussuaq region, no potential source rock for hydrocarbons has been reported in South Greenland, where Proterozoic gneisses and granites, igneous and sedimentary rocks are found. The youngest rocks in South Greenland are those of the Gardar Province (c. 1300-1100
$\mathrm{Ma}$ ), which is dominated by continental sandstones and lavas with numerous dykes and large intrusions (Poulsen 1964), one of which is the Ilímaussaq peralkaline intrusion. The Ilímaussaq intrusion solidified $3-4 \mathrm{~km}$ below the surface but is now exposed as a result of erosion. The latest uplift and erosion started c. $35 \mathrm{Ma}$ ago according to thermo-chronometric investigations (Japsen et al. 2006). However, the latest uplift phase was preceded by subsidence during Late Cretaceous to Eocene. During this subsidence phase the region was prob-
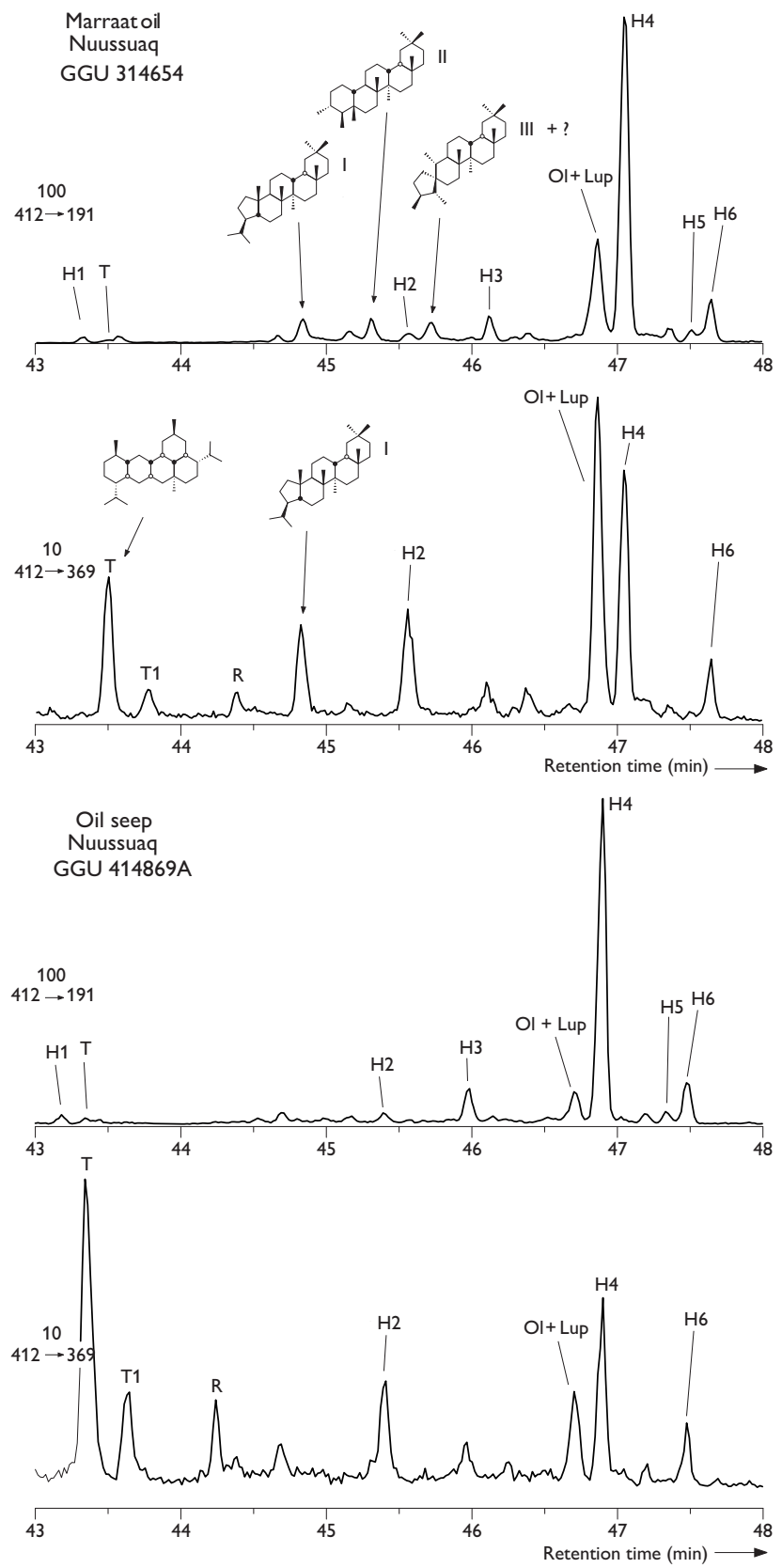
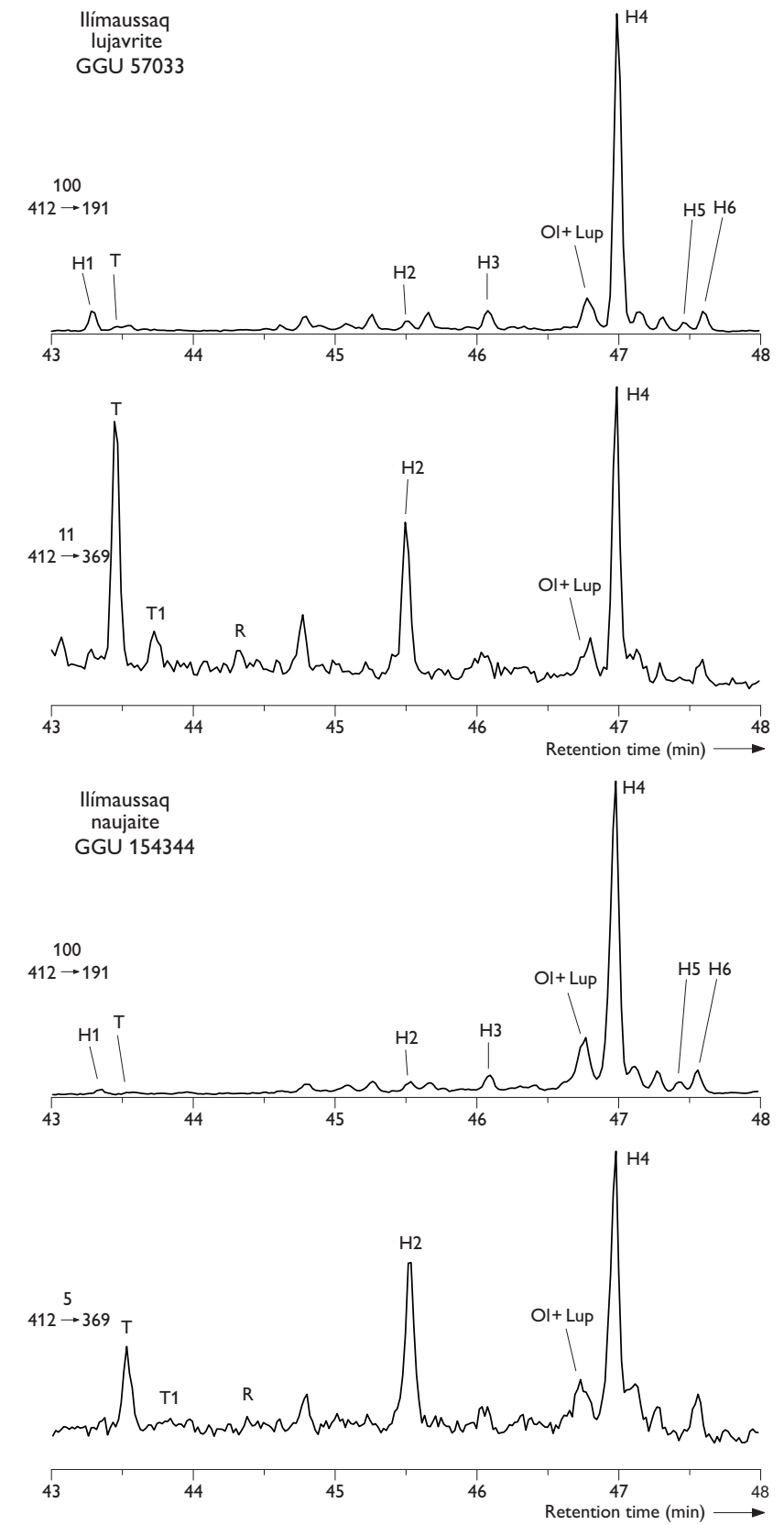

Fig. 4. Pentacyclic $\mathrm{C}_{30}$ triterpanes in an Ilímaussaq bitumen $(412 \rightarrow 191$ and $412 \rightarrow 369)$. Numbered peaks: oleananes (Ol + Lup) and similar land-plant components (I - III). Peaks H1-H6: hopanoids. Peaks T, T1 and R: bicadinanes. 

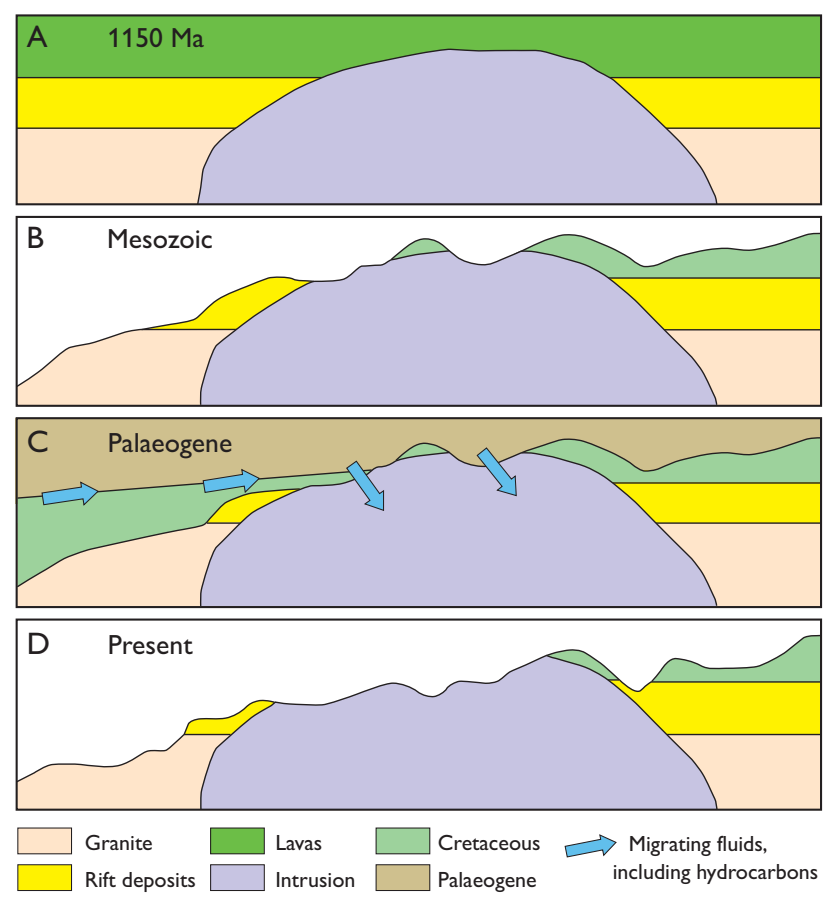

Fig. 5. Sketch of the geological evolution of the Ilímaussaq area.

ably covered by up to $2 \mathrm{~km}$ of marine sediments (Chalmers \& Pulvertaft 2001; Japsen et al. 2006). The reburial and uplift history in South Greenland was probably similar to that of West Greenland, including the Nuussuaq region (Bonow et al. 2007). Thus it is likely that hydrocarbons migrated from marine sediments into the rocks of the Ilímaussaq intrusion during the period of reburial (Fig. 5).

Hydrocarbons have only been reported from the Ilímaussaq intrusion and not from other rocks in South Greenland. There may be two reasons for this: (1) rocks from the Ilímaussaq intrusion have been studied in much more detail than other rocks due to the occurrence of rare minerals, some of which have economic potential, and (2) the Ilímaussaq intrusion may be more deeply weathered than other rocks in the region because it contains water-soluble minerals (RoseHansen \& Sørensen 2002).

From the biomarkers found in the bitumen, there is little doubt that the hydrocarbons were generated by thermal maturation of a marine source rock and migrated into the rocks of the Ilímaussaq intrusion at a later stage. It is unlikely that the bitumen formed by condensation of lighter hydrocarbons of abiogenic origin as hypothesised by Petersilie \& Sørensen (1970). Hydrocarbon gases in fluid inclusions in rocks from the Ilímaussaq intrusion were considered to be abiogenic in origin on the basis of the heavy isotopic value of methane (Petersilie \& Sørensen 1970; Konnerup-Madsen et al. 1988). However, they may also be of organic origin if the isotopic ratio of the gases was altered by fractionation due to diffusion of gases from the rocks (Laier \& Nytoft 2012).

\section{References}

Bojesen-Koefoed, J.A., Christiansen, F.G., Nytoft, H.P. \& Pedersen, A.K. 1999: Oil seepage onshore West Greenland: evidence of multiple source rocks and oil mixing. In: Fleet, A.J. \& Boldy, S.A.R. (eds): Petroleum geology of Northwest Europe. Proceedings of the 5th Conference. Petroleum Geology Conference Series 5, 305-314. London: Geological Society.

Bonow, J.M., Japsen, P., Green, P.F., Wilson, R.F., Chalmers, J.A., Klint, K.E., van Gool, J.A.M., Lidmar-Bergström, K. \& Pedersen, A.K. 2007: A multi-disciplinary study of Phanerozoic landscape development in West Greenland. Geological Survey of Denmark and Greenland Bulletin 13, 41-44.

Chalmers, J.A. \& Pulvertaft, T.C.R. 2001: Development of the continental margins of the Labrador Sea - a review. In: Wilson, R.C.L. et al. (eds): Non-volcanic rifting of continental margins: a comparison of evidence from land and sea. Geological Society Special Publications (London) 187, 79-107.

Christiansen, F.G. 2011: Greenland petroleum exploration: history, breakthroughs in understanding and future challenges. In: Spencer, A.M. et al. (eds): Arctic petroleum geology. Geological Society Memoirs (London) 35, 647-661.

Japsen, P., Bonow, J.M., Peulvast, J.-P. \&Wilson, R.W. 2006: Uplift, erosion and fault reactivation in Southwest Greenland. Field report summer 2006. Danmarks og Grønlands Geologiske Undersøgelse Rapport 2006/63, 77 pp.

Konnerup-Madsen, J., Larsen, E. \& Rose-Hansen, J. 1979: Hydrocarbonrich fluid inclusions in minerals from the alkaline Ilímaussaq intrusion, South Greenland. Bulletin de Minéralogie 102, 642-653.

Konnerup-Madsen J., Kreulen R. \& Rose-Hansen J. 1988: Stable isotopic characteristics of hydrocarbon gases in the alkaline Ilímaussaq complex, South Greenland. Bulletin de Minéralogie 111, 567-576.

Laier, T. \& Nytoft, H.P. 2012: Bitumen biomarkers in the mid-Proterozoic Ilímaussaq intrusion, Southwest Greenland - a challenge to the mantle gas theory. Marine and Petroleum Geology 30, 50-65.

Nytoft, H.P., Bojesen-Koefoed, J.A., Christiansen, F.G. \& Fowler, M.G. 2002: Oleanane or lupane? Reappraisal of the presence of oleanane in Cretaceous-Tertiary oils and sediments. Organic Geochemistry 33, $1225-1240$.

Poulsen, V. 1964: The sandstones of the Precambrian Eriksfjord Formation in South Greenland. Rapport Grønlands Geologiske Undersøgelse 2, 16 pp.

Petersilie, I.A. \& Sørensen, H. 1970: Hydrocarbon gases and bituminous substances in rocks from the Ilímaussaq alkaline intrusion, South Greenland. Lithos 3, 59-76.

Rose-Hansen, J. \& Sørensen, H. 2002: Geology of the lujavrites from the Ilímaussaq alkaline complex, South Greenland, with information from seven bore holes. Meddelelser om Grønland, Geoscience 40, 58 pp. 